\title{
REMEMBER YUGOSLAVIA?
}

\section{A crash course in business skills.}

\section{BY GARETH D. JONES}

$\mathrm{T}$ he board of directors sat across the table from Blake, an array of dark suits and expectant faces, waiting for him to speak. He had no idea what he was doing there.

I'm a salesman, darn it! I always know what to say. What worried Blake the most was that he couldn't remember standing up to address the board. He could ad-lib with the best of them, if he had a clue what the subject was.

"So, are you going to tell us about your trip to Yugoslavia?" the chairman asked, frowning.

Yugoslavia? Have I been there?

"Let me give you the background." Maeve stood up, auburn curls bouncing energetically, and smoothly took the floor. Blake sank into his chair gratefully.

"As you know, the international sports expo was the reunited republic's first big chance to show the rest of Europe what it had to offer..."

As Maeve talked, flashes of memory began to come to Blake: the flight from Stansted, the huge weather dome housing the expo, the sports facilities and exhibitions, the tennis coach...

"Now, that's impressive," Maeve said as they paused to watch the tennis match. For a change they weren't selling anything. SportTech UK had sent them to check out the competition, look for market opportunities, partnerships, something to give them the edge.

"Could be a ringer," Blake said. The tennis pro - a well-known Belgian champion - was facing tough competition from his opponent, supposedly a passing member of the public who had never played before. The woman wore a glossy black headband fixed tightly to her skull. Blake read the promo leaflet that the saleswoman who was dressed as a ball girl gave to him.

"Apparently the headband transmits the coach's skills," he said, intrigued. The coach sat in a motorized wheelchair at the far side of the tennis court, a matching headband affixed to his skull.

"That's just showing off," Maeve snorted. "They didn't need to use a paraplegic coach."

Blake shrugged, and watched the match for a few more minutes until Maeve wandered off elsewhere. It was impressive technology, but more high-end than they were looking for.

There was a blank in his memory.

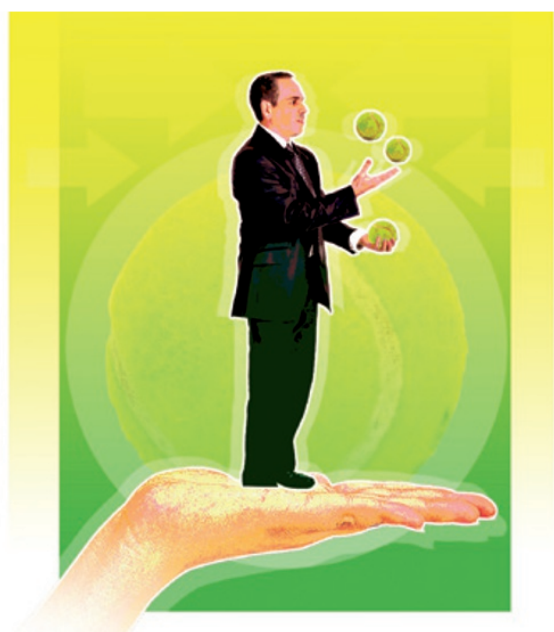

"Oh, go on, I'll give it a go," Blake said, allowing the ball girl to slide the headband snugly in position.

"There," she said with a pleasant Flemish accent. "It's not just for tennis of course." She showed him three tennis balls. "Do you juggle?"

"No."

"Well I do." She tapped her own headband and passed him the balls, one at a time. "Give it a go."

Blake weighed the tennis balls for a few seconds, then tossed the first in the air, followed by the second and the third. He was juggling! Then he dropped them.

"You tried to think about what you were doing." She smiled. "It's best to allow your subconscious to accept my direction." She picked the balls up. "Your mind can be trained to accept the skills from your coach."

"Did you hear?" Maeve asked, slipping into the seat next to Blake at the bar. The place was warm and noisy, packed with off-duty salesmen and sports enthusiasts.

Blake sipped his cider. "Hear what, particularly?"

"About the expo official, caught supplying financial information to an industrial spy?"

"No?" Blake's interest was piqued. Something other than sales to think about...

"She denies it of course, says she doesn't remember the meeting, even though it's caught on security footage."

Blake downed the remainder of his drink.

$\rightarrow$ NATURE.COM

Follow Futures on Facebook at: go.nature.com/mtoodm
"Maybe I won't remember meeting up with you either," he said, and called for another pint. He was still irritated at the way she'd taken over his chat with a pair of well-tanned sales execs elsewhere in the expo. According to their sales patter, their tablets stimulated melatonin levels to produce a natural tan in only an hour. Exactly the kind of cheap, mass-market product they were looking for.

The chairman appraised Blake over steepled fingers. "So Maeve has come back with a deal that makes us sole distributors of EasiTan in the UK, worth, what? Six million pounds?" She looked at Maeve.

"About six point two."

"Good. Excellent. And what did you get out of your little jaunt, Blake?"

There was an uncomfortable silence. Uncomfortable for Blake at least.

"I have to say that Blake was very good at sounding out the possibilities," Maeve offered.

Blake wasn't sure it helped.

"Next year's sports expo is in Belgium," the chairman said. "Let's hope you're still with us, shall we?”

Blake fiddled with the coins in his pocket as they took the lift down two floors, worried over his bizarrely fractured memories. "That didn't go so well," he said.

Maeve patted his shoulder sympathetically. "Next time keep your eye on the ball, not the ball girl."

"Ha!" He stuck out his tongue as she stepped out onto the sales office floor.

"I can't believe the mess Yugoslavia's in," she said as they walked the open-plan area to their desks.

"It is?"

"Weren't you paying any attention while we were there? The financial scandal has brought the government down." They sat at neighbouring desks and Blake leaned back in his chair as Maeve spoke. "The expo should've been worth a fortune to the economy, but it looks like Yugoslavia's first year together could be its last."

That gave Blake an idea.

"Are you listening?"

"Sorry, got something I need to do." He left his paper-strewn desk and headed back to the lift, feeling the urge to look up some company financial information. He pulled three pound coins from his pocket and juggled them as he walked.

Gareth D. Jones is an environmental scientist from the United Kingdom who also writes stories and drinks lots of tea. 